\title{
Interview med Michel Foucault
}

„At overvåge og straffe“ under kapitalismen og andetsteds. Fangslerne og magten.

En samtale med Michel Foucault, der har foregrebet tankerne $i$ den franske maj-bevagelse.

Af K. S. Karol.

Oversat fra „Il manifesto" af Victor Hjort.

$K S K$ : Fra og med „Klinikkens opståen“ og „Galskabens historie" og op til „At overvåge og straffe" har De gjort det til et centralt emne i Deres bøger at skildre problemet om dem, der udelukkes fra samfundet, dem som bliver spærret inde fordi de er sindssyge eller bliver forfulgt på grund af deres kriminelle eller politiske ,afvigelser“. De har skildret de forskellige former for intolerance i de førkapitalistiske samfund for at være bedre i stand til at analysere intolerancen - og fordømme den - sådan som den har udviklet sig og stadigvæk tager sig ud i det borgerlige samfund.

Deres tanker har haft en stærk indflydelse på studenternes protestbevægelse i '68 og De har desuden markeret Dem som en engageret filosof bl. a. ved at grundlægge G.i.p. (Groupe information prison). For nylig har de vestlige fjernseere haft mulighed for at se det f $\varnothing$ rste filmdokument fra en arbejdslejr i nærheden af Riga i Litauen og den forargelse optagelserne har vakt er så stor, at selv det franske kommunistparti har sagt fra.

$M F$ : Det der mest har gjort indtryk på mig er ikke disse optagelser, men de sovjetiske myndigheders modsigelser og hele det brede spektrum af småligt hykleri de byder på. Først har de bestridt, at dokumentet skulle være ægte. Senere har de erkendt, at lejren eksisterer men har, for at legitimere dette, hævdet, at de indsatte kun har begået almindelige forbrydelser. Formålet med at tvinge dem til at arbejde hårdt seks dage om ugen skulle være at give dem en ordentlig straf. De har også sagt noget andet, der har gjort indtryk på mig: „Det bedste bevis på, at der ikke er no- 
get at forarges over ved den lejr, er at den ligger midt $i$ en by og at alle kan se den." Som om det at placere en sådan lejr inde $\mathrm{i}$ en storby $\mathrm{i}$ stedet for at skjule den ude $\mathrm{i}$ en fjern skov, som tyskerne gjorde, skulle være en undskyldning. For mig at se er det derimod et endnu mere slående bevis. Det svarer nemlig nøjagtigt til det som fandt sted i det kapitalistiske Europa i det 19. årh., da de store fængsler blev bygget inde i bykernerne og ikke så langt vak fra domkirken, rådhuset og hospitalet, så ingen kunne undgå at se dem og netop opfatte dem som symboler på et straffesystem, der er en trussel mod både kvinder og mænd. Det samme gør sig gældende i Riga, hvor de sovjetiske myndigheder siger: "Vi skammer os ikke over det vi gør".

Og så har vi deres besynderlige alibi: „De indsatte er alligevel kun $\mathrm{d} \emptyset \mathrm{mt}$ for almindelige forbrydelser". Men den sovjetiske viceudenrigsminister har præciseret: „Hos os findes begrebet „politiske fanger“ ikke. Der findes ganske enkelt nogle kriminelle som boykotter vores sociale system og vores stat ved at foretage alskens ulovlige handlinger eller fremme bagvaskende propagan-

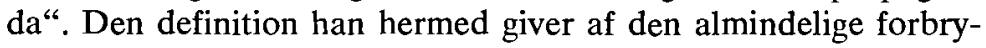
delse svarer til den som man andre steder giver af den politiske forbrydelse. $\mathrm{Og}$ på en måde er det helt logisk ud fra hans synspunkt. For hvis Sovjetunionen havde været et socialistisk samfund, der virkede som en sammenhængende social helhed, hvor individets interesser går $\mathrm{i}$ ét med samfundets, ville det ikke længere som i de kapitalistiske lande være muligt at betragte en forbrydelse som en privat handling, men kun et angreb mod den samlede sociale helhed. Der er bare den omstændighed, at man i et sådant samfund måtte have været nødsaget til at reagere på en politisk velovervejet måde, så individet politisk kan indse hvad han har gjort og dermed påny kan integreres $\mathrm{i}$ den sociale helhed.

Men de sovjetiske myndigheder farer ikke frem på denne måde: de har beholdt et straffesystem der er kalkeret efter vores - dvs. et ,almindeligt retssystem “ - og, hvad værre er, de undertrykker med konsekvent strenghed den eneste adfærd, om hvilken man nok kan sige at den er afvigende, men ikke kriminel: ønsket om at gå ud af det politiske system ved at forlade landet. Ser man f. eks. på tilfældet Kuznetsov, så hindrede man ham i at rejse ud på lovlig vis, hvorfor han blev nødsaget til at søge andre mid- 
ler til at flygte, der kostede ham en dødsdom, som senere blev omstødt til livsvarigt fængsel.

KSK: Men ligger forklaringen på disse paradokser ikke i det forhold, at Sovjetunionen foregiver at være en socialistisk stat uden at være det $\mathrm{i}$ virkeligheden? Jeg synes det er blevet tydeligt $\mathrm{i}$ den senere tid, at hvis dette samfund ikke er i stand til at finde nogle „selvkorrektionsmidler" - som man ellers syntes at skimte i anledning af SUKPs XX. kongres - så skyldes det nogle strukturelle fejl, der ligger i dets produktionsmåde, og ikke alene på det politiske ledelsesplan, som er mere eller mindre byrokratiseret. $M F$ : Det er da rigtigt, at man i Sovjet har modificeret principperne for ejendomsret og statens kontrol af produktionen, men ellers har man blot overtaget ledelsessystemer og magtudøvelsesmetoder fra det 19. årh.s Europa, hvor de blev udarbejdet. Såvel samfundsnormerne, de æstetiske former, de disciplinære metoder som alt det der fungerede i det borgerlige samfund omkring 1850 er blevet overført en bloc til det sovjetiske regime. Jeg mener, at fængselssystemet - som er emnet for min sidste bog „At overvåge og straffe“ - er blevet opfundet som et straffesystem, som blev udbredt $\mathrm{i}$ det 18 . årh. og praktiseret $\mathrm{i}$ det 19 . årh. i takt med udviklingen i de kapitalistiske samfund og det statsapparat, der svarede til det pågældende samfund. Fængselet er jo blot et led i de magtudøvelsesmetoder, som har været nødvendige for at sikre udviklingen af og kontrollen med produktivkræfterne. Fabriksdisciplinen, skoledisciplinen, militærdisciplinen og alle adfærdsdisciplinerne i almindelighed er tekniske opfindelser, der stammer fra den tid. Og al teknik kan overføres. Ligesom man i Sovjet har udnyttet „taylorismen“ og andre ledelsessystemer udarbejdet $\mathrm{i}$ Vesten, således har de taget vores disciplinsteknik $\mathrm{i}$ anvendelse.

KSK: Men man har også videreudviklet straffesystemet ved at spærre systemets modstandere inde på psykiatriske hospitaler. $M F:$ Nej, nej, også dette har historiske forløbere i vesten. Efter Pariserkommunen, da den store massakre og tvangsforflytningerne blev iværksat, foretrak man at anbringe de ,skyldige“ vel at mærke hvis de stammede fra et privilegeret borgerligt miljø - på sindssygeanstalterne. Men når vi ser på Sovjetunionen, så er det der foregår helt parakdoksalt. At indespærre en politisk modstander på et hospital er især uantageligt $i$ et land der kal- 
der sig socialistisk. Hvis det drejede sig om en morder eller en seksualforbryder, ville det måske være rimeligt at unders $\emptyset$ ge forbrydelsens bevæggrunde ved at unders $\varnothing$ ge forbryderens sygelige tilb $\varnothing$ jeligheder og fors $\varnothing$ ge at helbrede ham ved en egnet behandling - det ville i hvert fald ikke være helt ulogisk. Det modsatte gælder de politiske modstandere (jeg tænker på dem, der ikke anerkender systemet, ikke forstår det eller afviser det), idet det er mennesker som sovjetborgerne under ingen omstændigheder ville være tjent med at anse som syge. De politiske modstandere må udelukkende kunne underkastes en rent politisk behandling, der har til formål at åbne deres фjne og få dem til at forstå, hvorfor den sovjetiske virkelighed i h $\emptyset j$ grad både er menneskevenlig og ønskelig. Når man går ind for terapeutiske indgreb i stedet for overtalelsesmetoder, erkender man da ikke fra første færd i Sovjetunionen, at det er umuligt at bruge fornuftige argumenter og overbevise folk om at deres modstand er ubegrundet? Er det ikke det samme som at indr $\varnothing m m e$, at det eneste middel til at gøre den sovjetiske virkelighed menneskevenlig over for dem der ikke holder af den, består i at gribe ind med autoritære midler og $\mathrm{i}$ at påvirke deres hormoner og neuroner medicinsk? I virkeligheden betyder dette, at de sovjetiske ledere har opgivet at forklare og overtale og at de kun bekymrer sig om at få føjelighedsmekanismerne til at fungere.

$K S K$ : Men det at man tyr til disse udspekulerede metoder hænger sammen med en del af udviklingen i Sovjetunionen. Selve undertrykkelsen er i høj grad blevet mildnet og man oplever ikke længere den omfattende terror, som man for ikke alt for længe siden har kendt i dette land. Lad os tage et eksempel: ud af Videnskabernes Akademis 600 medlemmer har kun 60 rundt omkring i Sovjetunionen skrevet under på den tekst, der ford $\varnothing$ mte en af dem, Andrei Sakharov. Dette betyder, at de faktisk kan tillade sig at sige: „Nej tak, jeg vil ikke skrive under“. For tyve år siden havde dette været utænkeligt.

$M F$ : De hævder, at terroren nu er formindsket. Det er da også rigtigt. Men når det kommer til stykket, så er terror ikke udtryk for disciplinens højdepunkt, men tværtimod for dens fallit. Ingen af NKVDs* ledere i Stalin-tiden døde af naturlige årsager. Alle,

* Folkekommissariatet for Indenrigsanliggender, Indenrigsministeriet, hvorunder det hemmelige politi sorterede. 
selv dem der befandt sig på toppen af den sociale rangstige, var angst. Det man havde, var et yderst „bevægeligt" system, hvor ting kunne hænde og hvor ændringer kunne finde sted. Terror er altid reversibel, fordi den på en skæbnesvanger måde viser tilbage til dem, som udøver den. Angsten går i cirkler. Men i det $\emptyset$ jeblik både ministre, politikommissærer, akademikere, de ansvarlige fra partiet og alle de privilegerede ikke længere kan afsættes og ikke længere har noget at frygte, vil disciplinen indenfor de laveste lag fungere upåklageligt, ligesom der heller ikke længere vil være nogen mulighed - hvor illusorisk det ellers måtte forekomme - for et brud og et opror nedefra. Disciplinen hersker uden skygger og uden risici.

Vi må nemlig ikke glemme, at disciplinen blev opfundet under det 18. århundredes samfund, da borgerskabet var for opadgående, fordi terrormekanismerne på en gang både var blevet for dyre og for farlige. Hvori bestod da terroren igennem tiderne siden antikken? Det var hæren, der kastede sig over en befolkningsgruppe og lagde brande, plyndringer, voldtægt og massakrer bag sig. Hvis en konge ville hævne sig over et oprør, slap han sine tropper løs. Det var en imponerende, men kostbar metode, der ikke længere kan bruges i det $\emptyset$ jeblik, man kører med en nøje planlagt $\emptyset$ konomi, under hvilken man ikke længere kan ofre høsten, manufakturvarerne eller industrianlæggene, blot fordi nogle mennesker har gjort oprør.. Herfra stammer behovet for at finde en ny løsning, nemlig disciplinen.

KZ-lejren var en mellemløsning mellem den store terror og disciplinen, i den forstand at den dels fik folk til at gå til af angst, dels fik en del af befolkningen til at arbejde indenfor et disciplinært system med de samme egenskaber som kasernerne, hospitalerne og fabrikkerne, bare ti, hundrede, tusind gange værre ... $K S K$ : Jeg har indtryk af, at det må være endnu sværere for de sovjetiske borgere end for folk $\mathrm{i}$ Vesten at fatte hvilken betydning alle disse mekanismer har. Jeg mener, at et af beviserne på dette ligger i den kendsgerning, at en del af systemets modstandere i høj grad nærer fordomme over for de indsatte, der har begået almindelige forbrydelser. Den skildring Solsjenitsyn giver af de "almindelige“ indeholder ikke et gran af medlidenhed med dem.

$M F$ : Der er ingen tvivl om, at den fjendtlighed der udvises over 
for de ,almindelige“ fanger af dem der i USSR betragter sig som politiske fanger, kan virke chokerende på dem der opfatter kriminaliteten som en konsekvens af elendighed, oprørsånd og vægring mod at lade sig udbytte og trælbinde. Men man må se tingene $\mathrm{i}$ deres "taktiske“ relationer.

Jeg vil aldeles ikke hævde, at kommunisterne i USSR er magtens trofaste tjenere. Men jeg spekulerer på, om det ikke bliver en nødvendighed for de politiske modstandere - når man tager de ekstremt vanskelige forhold de må kæmpe under i betragtning at skille sig ud fra denne gruppe for at vise, at deres kamp ikke er den samme som „tyvenes og mordernes", som man ellers vil identificere dem med. Jeg formoder at mange modstandskæmpere, da de blev arresterede under den tyske besættelse, af politiske grunde fors $\varnothing$ gte at undgå at blive sammenlignet med sortbørstrafikanterne, som i øvrigt led en mindre grusom skæbne.

Hvis De stillede mig det samme spørgsmål vedrørende et land som Frankrig i vore dage, ville mit svar være anderledes. Jeg mener det må være nødvendigt at fremhæve den enestående "graduering", hvormed man vurderer ulovlighederne - på den ene side den undertiden estimerede og altid tolererede ulovlighed begået af den gaullistiske deputerede, der er indblandet $\mathrm{i}$ byggeskandaler, eller den begået af den store våben- eller narkotikatrafikant, folk som benytter sig af lovgivningen, og på den anden side den altid forfulgte og straffede ulovlighed begået af en småtyv, som forkaster loven, ignorerer den og tit bliver mast under den. Man burde påvise hvilken forskelsbehandling det strafferetslige system udsætter dem for. Den forskel det her er væsentligt at fremhæve, ligger ikke mellem de ,almindelige“ og de "politiske" lovovertrædere, men mellem dem der udnytter loven og begår indbringende ulovligheder, som fuldt ud tolereres, og de rudimentære ulovligheder, som det strafferetslige system benytter sig af for at skabe „kriminalitetsfunktionærer".

KSK: Men også i Vesten findes der en kløft mellem de folkelige lag og de „almindelige“ forbrydere. For nylig så jeg i det italienske fjernsyn en reportage $\mathrm{i}, \mathrm{A}-\mathrm{Z}$ " programmet, hvor slutbilledet viste en kirkegård inde i en fængselsgård. I en sådan kirkegård begraver man som katte, og i grave der ikke fortjener denne betegnelse, alle dem der er omkommet under fængselsopholdet. Familierne prøver ikke at få udleveret deres lig, fordi 
transporten er dyr og fordi de er flove. De sekvenser der blev vist har en meget dyb social betydning.

$M F$ : Bruddet mellem opinionen og forbryderne har den samme historiske baggrund som fængselssystemet. Eller rettere, det er en af de vigtige gevinster, som magten har vundet ved et sådant system.

Indtil det 18. årh. og i visse områder i Europa op til det 19. årh. og endda op til det 20 . årh. fandtes der ikke imellem forbryderne og de dybere lag i befolkningen det fjendtlige forhold, som der eksisterer $\mathrm{i}$ dag. Afstanden mellem de rige og de fattige var så stor, at kriminaliteten kun kunne udøves den ene vej. Man kunne ikke tage noget fra de fattige og den opfattelse, at tyven var en person, der var bitter på de rige, var temmelig udbredt blandt folket.

Op til 700-tallet kunne man nemt gøre en bandit eller en tyv til en historisk skikkelse. Mandrin, Guillery, o.s.v. nød i den folkelige mytologi en anseelse, der på trods af de negative sider, var meget positiv. Det samme gjaldt for de korsikanske og de sicilianske banditter, for de napolitanske tyve o.s.v. Denne kriminalitet, som blev akcepteret af folket - folk skjulte og beskyttede tyvene - begyndte at blive en alvorlig fare for det borgerlige samfund. Fra den stund, hvor rigdommen begyndte at tilflyde proletariatet, der med sit arbejde gjorde den produktiv, og fra den stund hvor de store værksteder og de enorme lagerrum opstod, da kunne borgerskabet ikke længere finde sig i den dagligdags tyveri- og røverivirksomhed, som man måtte leve med i det 18. årh., men som folket alligevel forholdt sig temmelig forstående over for.

Det har derfor på den ene side varet nødvendigt at beskytte den borgerlige rigdom mere effektivt og på den anden side at få folket til at indtage en klar negativ holdning over for forbryderne. Dermed skabte magten - bl. a. ved hjælp af fængslernes fremtrædende rolle - en samfundsgruppe af forbrydere uden reelle forbindelser til befolkningens dybere lag, en gruppe befolkningen stort set afviste, og som netop i kraft af denne isolation bedre kunne infiltreres af politiet og samtidig blive til grobund for den kriminalitetsideologi, der opstod i det 19. årh.

Det kan derfor ikke overraske, at befolkningen idag nærer mistro, foragt og had over for forbryderne: det er konsekvensen af 
et 150 år langt politimæssigt, politisk og ideologisk arbejde på den front. Man må heller ikke glemme, at tidligere straffede personer er blevet brugt som strejkebrydere og som ordensvagter mod arbejderne. Napoleons landsknægte var, som Marx også skrev, folk, der kom ud af fængslerne. I øvrigt lod en af kandidaterne til den franske republiks præsidentpost, Giscard d'Estaing, sig for nylig eskortere af straffede personer under sine valgmøder.

Det er en udbredt opfattelse hos mange, at kritikken af fængselssystemet og tanken om at man ikke bør straffe men forsøge at integrere de kriminelle i samfundet, først er blevet udformet i vores tid. Det passer ikke. Alt dette blev allerede debatteret melmel 1820 og 1850 . Man opdagede meget hurtigt - efter kun 10 år - at den mekanisme ikke virkede, at fængslet i de fleste tilfælde gjorde den dømte til en livsvarig forbryder. Tror De ikke, at man kunne have fundet frem til andre straffemetoder, hvis denne professionalisering af forbryderne ikke havde gjort det muligt at danne "en reservehær til rådighed for magten“ for at sikre nogle fordele som prostitutionen, for at skaffe politistikkere, drabanter, strejkebrydere, folk til at infiltrere fagforeningerne og i nyere tid livvagter til politikerne?

$K S K$ : Var målsætningen for „Groupe information prison“, hvor De har været aktiv, ikke netop den at udfylde den kløft, der skiller den folkelige opinion fra dem som den borgerlige justits har dømt?

$M F$ : Det arbejde vi må gøre idag, går ikke ud på at forherlige forbrydernes "marginale" rolle og deres "nomadekreativitet". Tværtimod må vi vise den folkelige bevægelse, inklusive fagforeningerne, at det er $\mathrm{i}$ vores interesse at integrere forbryderne $\mathrm{i}$ samfundet og unddrage dem det magtmisbrug de er udsat for. Jeg mener sådan set, at vi bør videreføre den form for politiske aktioner, som kaldes ,arbejde for og med masserne" - som blev både nyopdaget og nyaktiviseret efter 1968 - så vi kan vise folk, hvorledes dem der befinder sig på randen af samfundet, er blevet revet ud af deres omgivelser igennem ,selektionsmekanismer" ${ }^{\text {, }}$ som ikke altid er blottede for politifiduser. Og selv om det er sandt at fagforeningerne har vægtige historiske grunde for at nære mistro over for forbryderne, mener jeg deres taktik nu burde være en mobilisering for at nå ud til disse mennesker, så de 
ikke længere kan bruges af magten som tidligere.

$K S K$ : Det er mit indtryk, at man til en hvis grad har erkendt dette, selv inden for „borgerlige liberale“ kredse. For nylig bragte „Il Corriere della Sera“ (liberalt-konservativt dagblad med stort oplagstal og prestige, o.a.) en artikel på forsiden, der fordømte en mand i Palermo, der havde anmeldt sin $s \varnothing n$ for tyveri til politiet. Dagbladet forklarede, at den unge mand efter fængselsopholdet sandsynligvis ville blive til en langt farligere forbryder.

$M F$ : Det er der ingen tvivl om. Hvis den unge mand stjal biler før han kom i fængsel, vil han når han kommer ud stjæle hele togstammer. Men den artikel De her nævner udgør snarere en undtagelse. Som regel fors $\emptyset$ ger ængstelige „liberale" personer at afskrive deres ansvar med hensyn til det strafferetslige system, der hviler på pseudomoralske grundsætninger, og forskanser sig på pseudosamvittighedsfulde positioner ved at gå ind for brugen af medicin. If $\varnothing$ lge dem er medicin et „,neutralt" middel. Medicinen siger f. eks. ikke noget om at en homoseksuel bør straffes som sådan, ligesom den heller ikke kan udsige en moralsk dom over dem der stjæler eller bortfører en millionær. Den opstiller ikke nogen problemer. Dermed kan de alle gå med en gemen følelse af lettelse - det gælder dommere, sagførere, opinionen og journalister - når de bliver stillet over for den $\mathrm{i}$ både lovens og sandhedens navn velsignede skikkelse, der kommer og siger: „Nej, nej, I kan være helt rolige, I har ikke noget at skamme Jer over; I straffer ikke, men opdrager og helbreder takket være mig der er læge (psykiater eller psykolog)“. Og så siger dommerne til den sigtede: „Godt, i fængsel med dig“. De rejser sig tilfredse og lettede for enhver form for anger.

$K S K$ : Der findes efter min mening også en falsk men udbredt opfattelse inden for flere samfundssystemer, der går ud på at det manuelle arbejde udgør den bedste vej til frelse.

$M F$ : Det er noget, der allerede fandtes i det 19 . årh.s straffesystemer: hvis nogen begår en forbrydelse eller en lovovertrædelse, så mener man at det er fordi pågældende ikke bestiller noget. Hvis han havde haft et arbejde, dvs. hvis han var optaget i det disciplinære system, der fastbinder individet til sit arbejde, så ville han ikke have begået lovovertrædelsen. Hvordan bør han så straffes? Med arbejdet, naturligvis. Men det paradoksale er, at det arbejde, som fremstilles som en slags mirakelkur, bliver 
brugt som et middel til fysisk forfølgelse, der fra morgen til aften tvinger den dømte til at udføre det mest intetsigende ensformige, brutale, anstrengende, udmattende og til tider livsfarlige arbejde.

Det er en underlig blanding af målsætninger, der her ligger i arbejdet: straf, middel til moralsk omvendelse, resocialiseringsteknik, bodskriterium, kort sagt svaret på alle problemerne. Den måde man bruger arbejdet på i følge dette skema bliver endnu mere paradoksal i Sovjetunionen. Og så må man også vide hvad man snakker om: enten påtvinger man fangerne (det er sådan set ligegyldigt om de er ",almindelige“ eller „politiske“) et arbejde der er magen til det som alle sovjetborgerne har - men kan det så virkelig passe at dette ikke fremmedgjorte, ikke udbyttede og socialistiske arbejde er så modbydeligt, at det kun kan udf $\varnothing$ res bag pigtråd og med vagthunde i hælene? Eller så giver man dem underarbejde, et strafarbejde - og skal vi så tro, at et socialistisk land lader sine borgeres moralske og politiske opdragelse foregå ved hjælp af en så nedsættende karikatur af arbejdet? I фvrigt synes jeg heller ikke at Kina kan sige sig helt fri fra den paradoksale måde at bruge arbejdet som straf på.

$K S K$ : Jeg tror, at der i Kinas tilfælde er en forskel. For det første afviser det kinesiske regime at overtage en „,industrimodel“, der svarer til den vestlige eller til den sovjetiske. Kina stiler imod en meget ,anderledes“ udvikling, og til at begynde med prioriterer man ikke den kæmpestore industri til skade for landbruget. Dette modificerer i h $\emptyset \mathrm{j}$ grad den „disciplin“, som historisk set er knyttet til den „klassiske“ industrialisering. Således kender 80 procent af kineserne - dem som bor på landet - praktisk talt ikke til fængslerne. Man siger til dem: „I må selv klare jeres problemer og I må kun sende os folk der skal fængsles i de få tilfælde der er tale om livsfarlige forbrydere“.

Når man har sagt dette, må man tilføje at de også har arbejdslejre. Men i disse arbejdslejre benytter regimet sig ikke af forbryderne for at håndhæve disciplinen, ligesom det uden for ikke holder liv i forbryderverdenen for at overvåge eller kontrollere samfundet. Det er i følge alle vidnesbyrd, selv de antikommunistiske, en ubestridt nyskabelse, og jeg mener den er meget værdifuld. Så meget desto mere som Kina i begyndelsen i 1949 havde ry for at være et af verdens fattigste lande - og langt mere 
underudviklet end Sovjetunionen i 1917 - og for at være det land, der slog alle rekorder $\mathrm{i}$ organiseret kriminalitet og prostitution. I det mindste søger dets afsoningssystem at reintegrere mennesker i samfundet igennem en politisk skoling i stedet for at brutalisere dem og gøre dem til livsvarige forbrydere. Man kan nævne kejseren af Kina, der døde i sin egen seng, mens en monark i et andet land, der havde samarbejdet med den udenlandske fjende, garanteret ikke ville have nydt godt af den samme mildhed. Men bedre endnu er det at nævne Kuomintangs store ledere, alle de mænd, der havde ansvaret for borgerkrigen der varede 22 år og hvorunder der døde 50 millioner mennesker. I år er de allesammen blevet løsladt og de er blevet bevilget pas til at rejse til Formosa, hvis de skulle ønske det. Så folkerepublikken Kinas ledere er ikke bange for at de tidligere fanger fortæller om det de har set eller selv er blevet udsat for under fangenskabet.

$M F$ : Jeg har ingen særlig grund til at nære mistro til Kina. Men jeg vil straks understrege et par ting. Det ser ud til, som De siger, at kineserne ikke slår folk ihjel. Udmærket. Men jeg ved på den anden side ikke, om de i virkeligheden omskoler de skyldige, når der begås en politisk fejltagelse, og De må under alle omstændigheder indrømme, at de er meget dårlige til at omskole dem som har overværet fejltagelsen. Lad os tage Lin Piao affæren. Jeg ved ikke om de mennesker, der blev indblandet $\mathrm{i}$ denne „politiske forbrydelse“" er blevet omskolet, men jeg mener, at det kinesiske folk fortjener andre forklaringer på affæren, end dem som det er blevet givet.

$K S K$ : Her er jeg helt enig med Dem.

$M F$ : En anden ting: jeg er meget lykkelig for at kejseren kunne d $\varnothing$ blandt sine tulipaner, men der er nogen jeg har ondt af: jeg kender ikke hans navn, men det er den lille homoseksuelle barber, der offentligt blev henrettet $\mathrm{i}$ en KZ-lejr under overværelse af Pasqualini, en euroasiat der har skildret tildragelsen i sin erindringsbog. Denne bog er det eneste detaljerede dokument vi har om det kinesiske straffesystem.

Der er en ting der klart fremgår ved en læsning af hans bog, Karol: visse metoder, som „rødgardisterne“ brugte under kulturrevolutionen for at overbevise folk om deres fejl, ved at omskole, degradere eller latterliggøre dem, de svarer nøjagtigt til det som 
Pasqualini fortæller. Alt foregår som om arbejdslejrmetoderne var brudt frem for solens lys - jeg var lige ved at sige som hundrede, tusind blomster - i kulturrevolutionens Kina. Der er en meget urovækkende lighed mellem de hændelser, som blev bevidnet af millioner af mennesker under kulturrevolutionen og de hændelser, der blev oplevet $i$ en lejr fire eller fem år tidligere.

KSK: Den kritik af „rødgardisternes“ opførsel, som Mao fremførte i et interview med Snow i 1970 er ligeså alvorlig, selv om den ikke begrunder fænomenet med den måde arbejdslejrene fungerer på. Og på trods af mange skuffelser talte Mao om nye kulturrevolutioner og opfordrede til umiddelbart at skabe „skoler med åbne døre“", fuldstændigt nygrundlagte og anti-elitære universiteter, en hær uden rangordener og fabrikker med mindst muligt hierarki. Mener De ikke, at disse indgreb er helt uforenelige med de disciplinære metoder, som er blevet udviklet inden for alle disse sektorer i løbet af industrialiseringen i Europa - og senere i Sovjetunionen?

$M F$ : Jeg kan absolut ikke sige nej og da jeg ingen grund har til at sige det modsatte, siger jeg foreløbig jo. Under alle omstændigheder ville kineserne nok anbefale mig at beskæftige mig med Frankrig.

Man har længe spekuleret over hvad det var man skulle straffe, og ligeså længe over hvilken måde man skulle straffe på. Og nu stilles det mærkelige spørgsmål: „Er det nødvendigt at straffe?“. „Hvad betyder det at straffe?" . „Hvorfor er der en så tydelig forbindelse mellem forbrydelse og straf?“. At en forbrydelse bør straffes forekommer os meget naturligt, meget nærliggende, meget nødvendigt, men samtidig som noget uklart og tvivlsomt. At foreslå en ,anden løsning“ for at straffe, er det samme som at indtage en forældet holdning over for problemet, der ikke drejer sig om straffens juridiske eller tekniske aspekt, men om magten som den instans der straffer.

Det er derfor jeg interesserer mig for det sæt af straffenormer man har i Sovjetunionen. Man kan selvfølgelig more sig over de teoretiske modsigelser, der præger den sovjetiske straffepraksis; men det er teorier der slår ihjel og modsigelser der er besudlet med dynd og blod. Man kan undre sig over, at man i Sovjet ikke har været $\mathrm{i}$ stand til at udarbejde nye holdninger til forbrydelser, lovovertrædelser eller forskellige former for modstand mod re- 
gimet; man kan, bør forarges over at man har overtaget metoder, som ,,borgerskabet“ brugte i sine strengeste perioder i begyndelsen af 1800-tallet og at man har udviklet dem på en så omfattende og grundig måde både $\mathrm{i}$ retning af det uendeligt store og af det uendeligt lille, der kun kan forblфffe.

Magtmekanismerne, kontrol-, straffe- og overvågelsessystemerne har derovre et ukendt omfang og er de samme som borgerskabet (dog med meget mere begrænsede og usikre former) havde behov for for at konsolidere sit overherredømme. Alt dette kan siges om mange enten tankte eller realiserede former for socialisme; midt imellem analysen af magten i den borgerlige stat og tesen om statens forfald mangler der analyser og kritik med henblik på en nedbrydning og en omvæltning af magtmekanismerne. Socialismen har ingen behov for et nyt frihedscharter eller for en ny erklæring om menneskerettighederne: det ville være for nemt og til ingen nytte. Hvis socialismen skal fortjene at blive afholdt $i$ stedet for at byde imod, må den kunne besvare spørgsmålet vedrørende magten og den måde den udøves på. Den må opfinde en form for magtudøvelse der ikke skaber frygt. Det er her nyheden ville være at finde. 